\title{
Effect of $\mathrm{TiB}_{2}$ content on microstructure and mechanical properties of in-situ fabricated $\mathrm{TiB}_{2} / \mathrm{B}_{4} \mathrm{C}$ composites
}

\author{
WANG Yu-jin ${ }^{1,2}$, PENG Hua-xin ${ }^{2}$, YE Feng ${ }^{1}$, ZHOU Yu ${ }^{1}$ \\ 1. Institute for Advanced Ceramics, School of Materials Science and Engineering, \\ Harbin Institute of Technology, Harbin 150001, China; \\ 2. Advanced Composites Centre for Innovation and Science (ACCIS), Department of Aerospace Engineering, \\ Faculty of Engineering, University of Bristol, Queens Building, University Walk, Bristol BS8 1TR, UK
}

Received 10 May 2011; accepted 25 July 2011

\begin{abstract}
The fully dense boron carbide matrix composites containing $10 \%-40 \%$ (volume fraction) $\mathrm{TiB}_{2}\left(\mathrm{TiB}_{2} / \mathrm{B}_{4} \mathrm{C}\right)$ were in-situ fabricated via chemical reaction of $\mathrm{B}_{4} \mathrm{C}, \mathrm{TiO}_{2}$ and graphite powders at $2050{ }^{\circ} \mathrm{C}$ under a pressure of $35 \mathrm{MPa}$. Scanning electron microscopy (SEM) and transmission election microscopy (TEM) observations show that the sub-micron/nano-sized $\mathrm{TiB}_{2}$ particles are uniformly located within the matrix grains and at the $\mathrm{B}_{4} \mathrm{C}$ grain boundaries. With the increase of $\mathrm{TiB}_{2}$ content, the elastic modulus and fracture toughness of composites increase remarkably. However, the situation is reversed for Vickers hardness and flexural strength. The fracture toughness exhibits a maximum value of $8.2 \mathrm{MPa} \cdot \mathrm{m}^{1 / 2}$ for the $40 \%$ (volume fraction) $\mathrm{TiB}_{2} / \mathrm{B}_{4} \mathrm{C}$ composite. The main toughening mechanisms of $\mathrm{TiB}_{2} / \mathrm{B}_{4} \mathrm{C}$ composites are microcrack toughening and crack deflection toughening.
\end{abstract}

Key words: $\mathrm{TiB}_{2} / \mathrm{B}_{4} \mathrm{C}$ composites; in-situ reaction; toughening mechanisms

\section{Introduction}

Boron carbide $\left(\mathrm{B}_{4} \mathrm{C}\right)$ ceramics have been widely used for a variety of structural applications due to their extremely high hardness, wear resistance, low specific gravity and high chemical stability. However, the boron carbide used as a structural material was limited by two major drawbacks, namely, the low fracture toughness of $\mathrm{B}_{4} \mathrm{C}$ and the very high temperature required for its sintering. Nearly, fully densification cannot be achieved by pressureless sintering and can be attained in pure $\mathrm{B}_{4} \mathrm{C}$ only by hot pressing above $2300{ }^{\circ} \mathrm{C}$ [1]. Many efforts have been made to improve the densification of $\mathrm{B}_{4} \mathrm{C}$ by introducing sintering aids including metals (Al, Ti) [2-3], oxides $\left(\mathrm{Al}_{2} \mathrm{O}_{3}, \mathrm{ZrO}_{2}\right)[4-5]$ and non-oxides $\left(\mathrm{W}_{2} \mathrm{~B}_{5}\right.$, TiC) [6-7], as well as $\mathrm{B}$ and $\mathrm{C}$ [8-9].

Recently, it has been found that the addition of $\mathrm{TiO}_{2}$ into $\mathrm{B}_{4} \mathrm{C}$ along with the stoichiometric amount of $\mathrm{C}$ greatly reduces the sintering temperature and increases the toughness and strength [10]. The sintering process involves the conversion of $\mathrm{TiO}_{2}$ to $\mathrm{TiB}_{2}$ according to the following reaction:

$2 \mathrm{TiO}_{2}+3 \mathrm{C}+\mathrm{B}_{4} \mathrm{C} \rightarrow 2 \mathrm{TiB}_{2}+4 \mathrm{CO} \uparrow$
The $\mathrm{TiB}_{2}$ phase serves as a strengthening and toughening agent whose presence results in an increase in bend strength to over $500 \mathrm{MPa}$ [10-15]. A flexural strength of $866 \mathrm{MPa}$ and fracture toughness of 3.2 $\mathrm{MPa} \cdot \mathrm{m}^{1 / 2}$ were reported for fully dense $\mathrm{B}_{4} \mathrm{C}-15 \%$ (volume fraction) $\mathrm{TiB}_{2}$ composites prepared from a mixture $\mathrm{B}_{4} \mathrm{C} / \mathrm{TiO}_{2} /$ carbon black powders via reactive hot pressing for $1 \mathrm{~h}$ at $2000{ }^{\circ} \mathrm{C}$ under a pressure of $50 \mathrm{MPa}$ [16]. A mixture of fine-sized $\mathrm{B}_{4} \mathrm{C}$ with $40 \%$ (mass fraction) $\mathrm{TiO}_{2}$ was transformed into a $95 \%$ dense $\mathrm{B}_{4} \mathrm{C}-\mathrm{TiB}_{2}$ composite fabricated at $2160{ }^{\circ} \mathrm{C}$ for $1 \mathrm{~h} \mathrm{[17]}$. In the present study, in order to improve the mechanical properties of $\mathrm{B}_{4} \mathrm{C}$ ceramics, $\mathrm{B}_{4} \mathrm{C}-\mathrm{TiB}_{2}$ composites were in-situ synthesized by hot pressing. Furthermore, the effect of the in-situ $\mathrm{TiB}_{2}$ on microstructure and mechanical properties of $\mathrm{TiB}_{2} / \mathrm{B}_{4} \mathrm{C}$ composites was investigated.

\section{Experimental}

Commercially available $\mathrm{B}_{4} \mathrm{C}$ powder with an average particle size of $3.5 \mu \mathrm{m}$ was used. The $\mathrm{B}_{4} \mathrm{C}$ powder was mixed with high purity $(99.9 \%)$ nano-size $\mathrm{TiO}_{2}$ (smaller than $50 \mathrm{~nm}$ ) and graphite powders by 
ball-milling for $12 \mathrm{~h}$ using alcohol as a vehicle. Mixing was performed in a plastic jar with agate balls as a milling media. In order to gain the sintered compositions containing $10 \%, 20 \%, 30 \%$, and $40 \%$ (volume fraction) $\mathrm{TiB}_{2}$, the levels of $\mathrm{TiO}_{2}$ and $\mathrm{C}$ were adjusted according to the stoichiometry of Eq. (1) (see Table 1 for the green compositions). The blended powders were dried at $75^{\circ} \mathrm{C}$ for $20 \mathrm{~h}$. All samples were sintered at $1850^{\circ} \mathrm{C}$ for $0.5 \mathrm{~h}$, and then hot-pressed for $1 \mathrm{~h}$ at $2050{ }^{\circ} \mathrm{C}$ under a pressure of $35 \mathrm{MPa}$ in a vacuum of $1.3 \times 10^{-3} \mathrm{~Pa}$. The heating rates were $20^{\circ} \mathrm{C} / \mathrm{min}$ from room temperature to $1850{ }^{\circ} \mathrm{C}$ and $10^{\circ} \mathrm{C} / \mathrm{min}$ from 1850 to $2050^{\circ} \mathrm{C}$, respectively.

Table 1 Green specimen compositions

\begin{tabular}{ccccccc}
\hline \multicolumn{3}{c}{ Green } & & \multicolumn{4}{c}{ Sintered } \\
\cline { 1 - 3 } \cline { 5 - 7 } $\begin{array}{c}w\left(\mathrm{~B}_{4} \mathrm{C}\right) / \\
\%\end{array}$ & $\begin{array}{c}w\left(\mathrm{TiO}_{2}\right) / \\
\%\end{array}$ & $\begin{array}{c}w(\mathrm{C}) / \\
\%\end{array}$ & & $\begin{array}{c}\varphi\left(\mathrm{B}_{4} \mathrm{C}\right) / \\
\%\end{array}$ & $\begin{array}{c}\varphi\left(\mathrm{TiB}_{2}\right) / \\
\%\end{array}$ & $\begin{array}{c}\text { Theoretical } \\
\text { density/ } \\
\left(\mathrm{g} \cdot \mathrm{cm}^{-3}\right)\end{array}$ \\
\hline 79.42 & 16.79 & 3.79 & 90 & 10 & 2.718 \\
65.19 & 28.41 & 6.40 & 80 & 20 & 2.916 \\
54.75 & 36.92 & 8.33 & 70 & 30 & 3.114 \\
46.77 & 43.44 & 9.79 & 60 & 40 & 3.312 \\
\hline
\end{tabular}

Phase structure was identified by X-ray diffraction (XRD) analysis. The bulk density was measured by the Archimedes method. The hardness was evaluated by Vicker's indentation. The flexural strength was measured by a three-point bending test. The fracture toughness was measured by a single edge notch beam test. The polished surfaces were examined by SEM. The microstructure of the composites was investigated by TEM.

\section{Results and discussion}

All the $\mathrm{TiB}_{2} / \mathrm{B}_{4} \mathrm{C}$ composites fabricated by reaction hot-pressing exhibit almost fully densities. The $\mathrm{TiB}_{2}$ synthesized by in-situ reaction clearly promotes the densification of boron carbide in the sintering process. From XRD analysis, no $\mathrm{TiO}_{2}$ or $\mathrm{C}$ was detected in all of samples (as shown in Fig. 1). Only $\mathrm{B}_{4} \mathrm{C}$ and $\mathrm{TiB}_{2}$ phases were identified, although the presence of a small amount of oxygen or carbon cannot be ruled out.

Typical polished microstructures of various sintered $\mathrm{TiB}_{2} / \mathrm{B}_{4} \mathrm{C}$ composites (as shown in Fig. 2), consist of boron carbide (gray) and titanium diboride (white). In all the specimens, $\mathrm{TiB}_{2}$ particles were dispersed in the $\mathrm{B}_{4} \mathrm{C}$ matrix homogeneously. The average $\mathrm{B}_{4} \mathrm{C}$ grain size decreases with the increase of $\mathrm{TiB}_{2}$ volume fraction. The $\mathrm{TiB}_{2}$ particles inhibit the increase of grain size. Most of grain sizes of the $\mathrm{TiB}_{2}$ and $\mathrm{B}_{4} \mathrm{C}$ are less than $5 \mu \mathrm{m}$. The largest $\mathrm{B}_{4} \mathrm{C}$ grains have visible twinned structure (as shown in Fig. 3(a)). These grains might have been

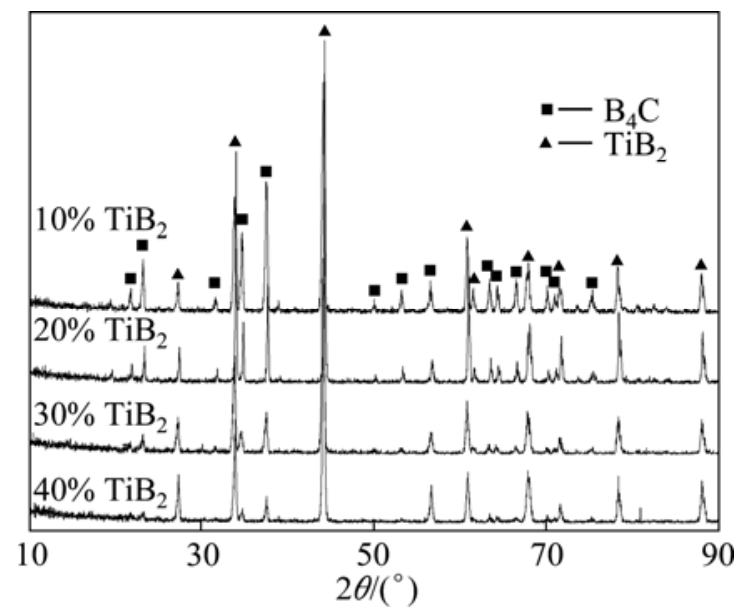

Fig. 1 XRD patterns of $\mathrm{TiB}_{2} / \mathrm{B}_{4} \mathrm{C}$ composites

subjected to high internal shear stress in cooling from the elevated temperatures, most likely due to thermal expansion anisotropy. In addition, some dislocation lines or loops were found near the small $\mathrm{TiB}_{2}$ particles in the $\mathrm{B}_{4} \mathrm{C}$ grains (as shown in Fig. 3(b)). It may be attributed to the thermal mismatch between $\mathrm{TiB}_{2}$ and $\mathrm{B}_{4} \mathrm{C}$. From Figs. 3(c) and (d), the $\mathrm{TiB}_{2}$ particles can be classified into two types: as above-mentioned small equiaxial nano-sized $\mathrm{TiB}_{2}$ particles $(20-150 \mathrm{~nm})$ confined within larger boron carbide grains, and large, irregularly shaped $\mathrm{TiB}_{2}$ particles (or particle clusters) located at the grain boundaries or triple junctions. The particles with grain boundary tend to coarsen, while those confined within the grains retain their initial size. This implies that the grain boundary is the major mass-transfer path for $\mathrm{TiB}_{2}$ coarsening.

The variations of Vicker's hardness (Hv), elastic modulus $(E)$, flexural strength and fracture toughness of $\mathrm{B}_{4} \mathrm{C} / \mathrm{TiB}_{2}$ composites with $\mathrm{TiB}_{2}$ volume fraction are shown in Figs. 4 and 5. The increase of $\mathrm{TiB}_{2}$ content from $10 \%$ to $40 \%$ (volume fraction) results in a decrease in $\mathrm{Hv}$ due to the lower hardness of $\mathrm{TiB}_{2}$ than that of $\mathrm{B}_{4} \mathrm{C}$ and the rule of mixtures. The elastic modulus increases with increase of $\mathrm{TiB}_{2}$ content, which is attributable to high elastic modulus for $\mathrm{TiB}_{2}$. With adding $40 \%$ (volume fraction) $\mathrm{TiB}_{2}$, the elastic modulus of the composite is $526 \mathrm{GPa}$, which is $15 \%$ higher than that of $10 \%$ (volume fraction) $\mathrm{TiB}_{2} / \mathrm{B}_{4} \mathrm{C}$.

As shown in Fig. 5, the addition of $\mathrm{TiB}_{2}$ has significant effects on the flexural strength and the fracture toughness of $\mathrm{B}_{4} \mathrm{C}$. The fracture toughness increases steadily with the increase of $\mathrm{TiB}_{2}$ content, as shown in Fig. 5. The maximum value is $8.2 \mathrm{MPa} \cdot \mathrm{m}^{1 / 2}$ for $40 \%$ (volume fraction) $\mathrm{TiB}_{2}$. It depends upon the presence of uniformly distributed $\mathrm{TiB}_{2}$ particles and a well sintered fine-grained $\mathrm{B}_{4} \mathrm{C}$ matrix. The thermal 


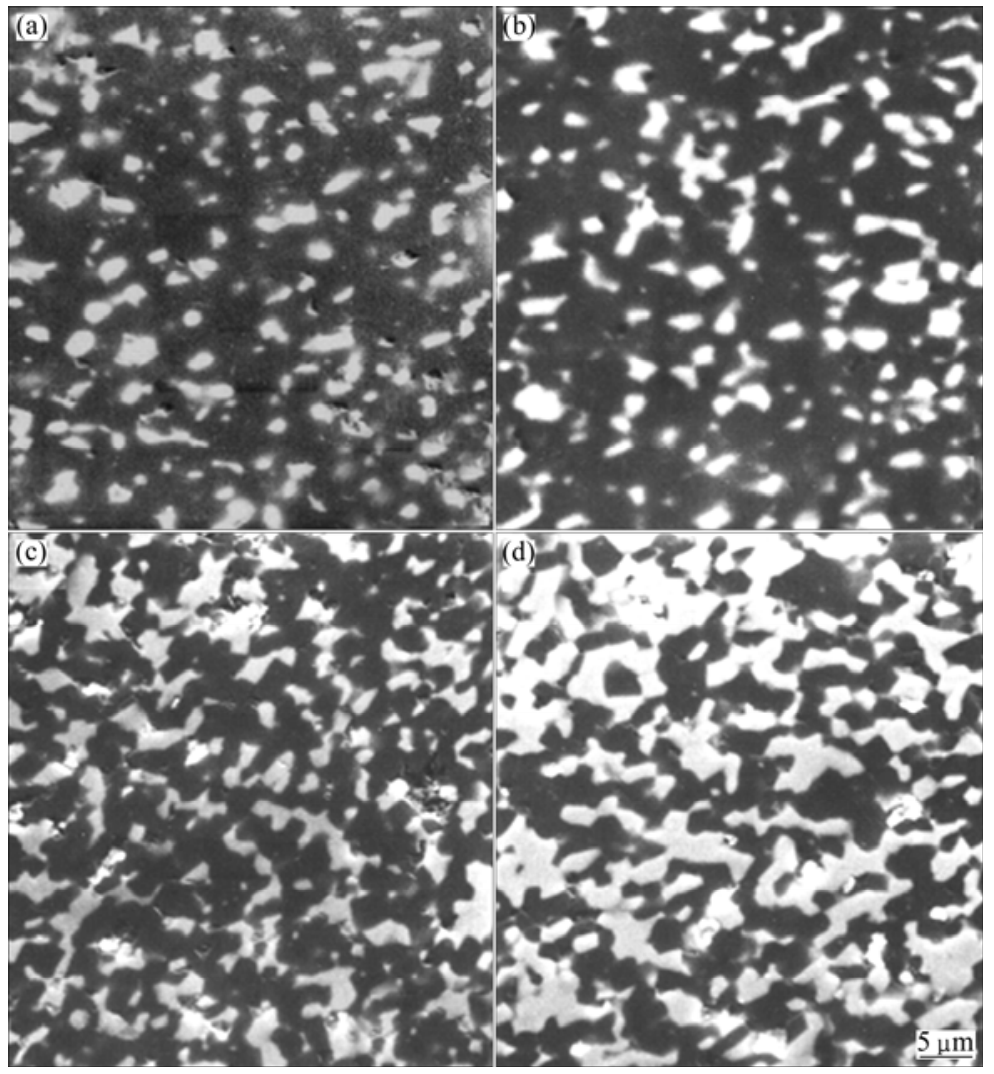

Fig. 2 SEM images of polished $\mathrm{TiB}_{2} / \mathrm{B}_{4} \mathrm{C}$ composites: (a) $10 \% \mathrm{TiB}_{2} / \mathrm{B}_{4} \mathrm{C}$; (b) $20 \% \mathrm{TiB}_{2} / \mathrm{B}_{4} \mathrm{C}$; (c) $30 \% \mathrm{TiB}_{2} / \mathrm{B}_{4} \mathrm{C}$; (d) $40 \% \mathrm{TiB} / \mathrm{B}_{4} \mathrm{C}$
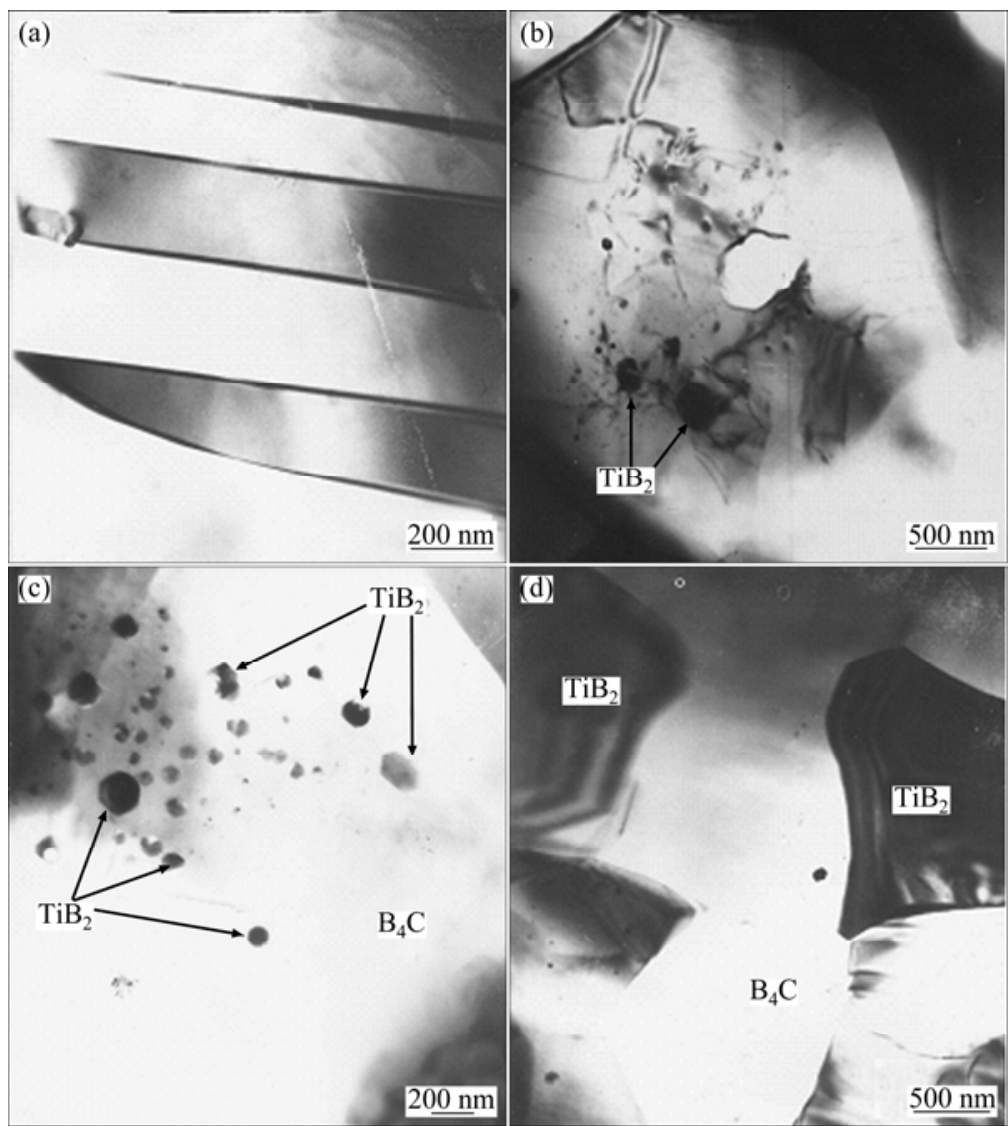

Fig. 3 TEM images of $\mathrm{TiB}_{2} / \mathrm{B}_{4} \mathrm{C}$ composites: (a) Twinned structure in $\mathrm{B}_{4} \mathrm{C}$; (b) Dislocation microstructure near small $\mathrm{TiB}_{2}$ particles in $\mathrm{B}_{4} \mathrm{C}$ grains; (c) Nano-sized $\mathrm{TiB}_{2}$ particles in $\mathrm{B}_{4} \mathrm{C}$ grain; (d) Large $\mathrm{TiB}_{2}$ particles located at grain boundaries or triple junctions 


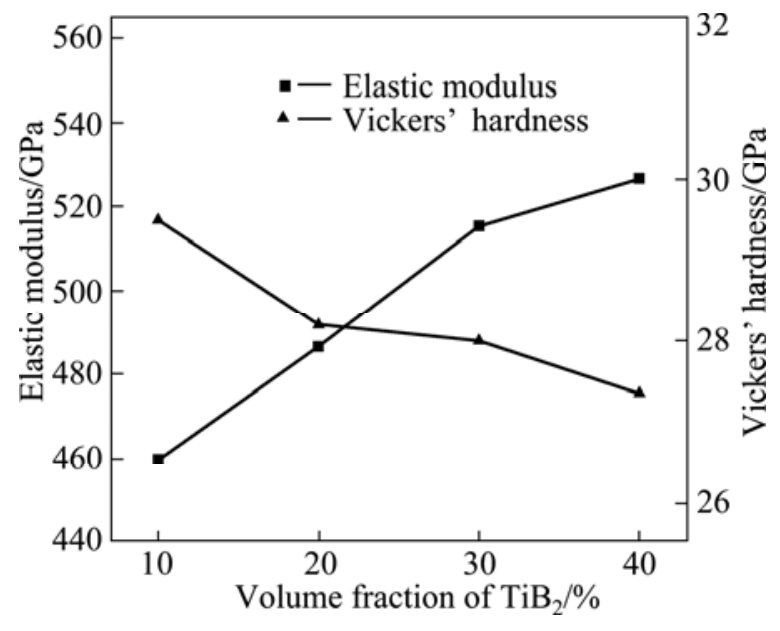

Fig. 4 Elastic modulus and Vickers' hardness as function of $\mathrm{TiB}_{2}$ volume fraction for $\mathrm{TiB}_{2} / \mathrm{B}_{4} \mathrm{C}$ composites

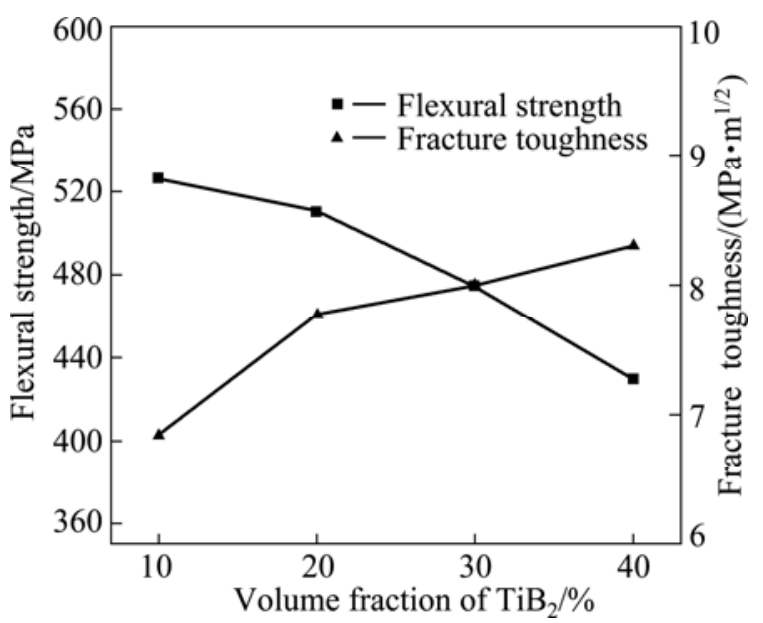

Fig. 5 Flexural strength and fracture toughness as function of volume fraction of $\mathrm{TiB}_{2}$ for $\mathrm{TiB}_{2} / \mathrm{B}_{4} \mathrm{C}$ composites

expansion mismatch stress developed in cooling to room temperature places the $\mathrm{TiB}_{2} / \mathrm{B}_{4} \mathrm{C}$ boundary under the tensile stress and leads to partial or full fracture of the interface due to a large difference in the linear thermal expansion between $\mathrm{B}_{4} \mathrm{C}$ and $\mathrm{TiB}_{2}$. As calculated by SKOROKHOD and KRSTIC [10], the residual stress is about $1 \mathrm{GPa}$. The large boundary stress is sufficient to break the interface and cause microcracking followed by a partial or full relaxation of the stress. The crack with size less than their presence has positive effects on the fracture toughness. In addition, from Fig. 6, crack deflection occurs around the $\mathrm{TiB}_{2}$ particles for the $20 \%$ (volume fraction) $\mathrm{TiB}_{2} / \mathrm{B}_{4} \mathrm{C}$ composite.

Different from fracture toughness, the flexural strength decreases slowly from 526 to $429 \mathrm{MPa}$ with adding $40 \%$ (volume fraction) $\mathrm{TiB}_{2}$. It may weaken the effect of residual stresses and microcracks.

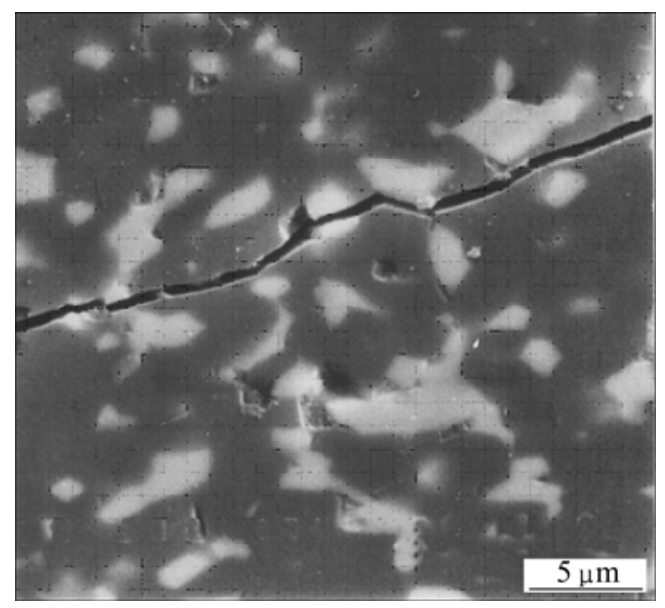

Fig. 6 Crack deflection on $20 \%$ (volume fraction) $\mathrm{TiB}_{2} / \mathrm{B}_{4} \mathrm{C}$ composite specimen

\section{Conclusions}

1) $\mathrm{TiB}_{2} / \mathrm{B}_{4} \mathrm{C}$ composites exhibit a composite microstructure where $\mathrm{TiB}_{2}$ particles are dispersed uniformly in a fine grained $\mathrm{B}_{4} \mathrm{C}$ matrix.

2) The fracture toughness increases steadily with increasing $\mathrm{TiB}_{2}$ content, reaching the maximum value of $8.2 \mathrm{MPa} \cdot \mathrm{m}^{1 / 2}$ at $40 \%$ (volume fraction) $\mathrm{TiB}_{2}$.

3) The main toughening mechanisms are microcracks toughening and deflection toughening of propagating cracks caused by the thermal expansion mismatch between $\mathrm{TiB}_{2}$ and $\mathrm{B}_{4} \mathrm{C}$.

\section{References}

[1] TELLE R. In materials science and technology [M]. CAHN R W, HANSEN P, KRAMER J. New York: NY, 1994: 175-258.

[2] VIALA J C, BOUIX J, GONZALEZ G, ESNOUF C. Chemical reactivity of aluminium with boron carbide [J]. J Mater Sci, 1997, 32: 4559-4573.

[3] MOGILEVSKY P, GUTMANAS E Y, GOTMAN I, TELLE I. Reaction formation of coatings at boron carbide interface with Ti and Cr powders [J]. J Eur Ceram Soc, 1995, 15: 527-535.

[4] KIM H W, KOH Y H, KIM H E. Densification and mechanical properties of $\mathrm{B}_{4} \mathrm{C}$ with $\mathrm{Al}_{2} \mathrm{O}_{3}$ as a sintering aid [J]. J Am Ceram Soc, 2000, 83: 2863-2865.

[5] KIM H W, KOH Y H, KIM H E. Reaction sintering and mechanical properties of $\mathrm{B}_{4} \mathrm{C}$ with addition of $\mathrm{ZrO}_{2}$ [J]. J Mater Res, 2000, 15: 2431-2436.

[6] ZAKHARIEV Z, RADEV D. Properties of polycrystalline boron carbide sintered in the presence of tungsten boride $\left(\mathrm{W}_{2} \mathrm{~B}_{5}\right)$ without pressing [J]. J Mater Sci Lett, 1988, 7: 695-696.

[7] SIGL L S. Processing and mechanical properties of boron carbide sintered with TiC [J]. J Euro Ceram Soc, 1998, 18: 1521-1529.

[8] ZHAO L, WU L, HUANG Q, YANG Q. Structure of C-B 4 C-SiC composites with silicon additive [J]. J Mater Sci Lett, 1996, 15: 353-356.

[9] KALANDADZE G I, SHALAMBERIDZE S O, PEIKRISHVILI A. B. Sintering of boron and boron carbide [J]. J Solid State Chem, 2000, 154: 194-198. 
[10] SKOROKHOD V, KRSTIC V D. High strength-high toughness $\mathrm{TiB}_{2}-\mathrm{B}_{4} \mathrm{C}$ composites [J]. J Mater Sci Lett, 2000, 19: 237-239.

[11] RU Hong-qiang, XU Hai-fei, YU Liang, LÜ Peng. Study on in-suit synthetic $\mathrm{TiB}_{2} / \mathrm{B}_{4} \mathrm{C}$ composites by co-precipitating [J]. Rare Metal Materials and Engineering, 2007, 36(s1): 717-720. (in Chinese)

[12] SUN J L, LIU C X, DUAN C Y. Effect of $\mathrm{Al}$ and $\mathrm{TiO}_{2}$ on sinterability and mechanical properties of boron carbide [J]. Mat Sci Eng A, 2009, 509: 89-93.

[13] SRIVATSAN T S, GURUPRASAD G, BLACK D, RADHAKRISHNAN R, SUDARSHAN $\mathrm{T} S$. Influence of $\mathrm{TiB}_{2}$ content on microstructure and hardness of $\mathrm{TiB}_{2}-\mathrm{B}_{4} \mathrm{C}$ composite $[\mathrm{J}]$. Powder Technol, 2005, 159: 161-167.

[14] BOGOMOL I, NISHIMURA T, VASYLKIV O, SAKKA Y,
LOBODA P. Microstructure and high-temperature strength of $\mathrm{B}_{4} \mathrm{C}-\mathrm{TiB}_{2}$ composite prepared by a crucibleless zone melting method [J]. J Alloys Compd, 2009, 485: 677-681.

[15] YUE X Y, ZHAO S M, LÜ P, CHANG Q, RU H Q. Synthesis and properties of hot pressed $\mathrm{B}_{4} \mathrm{C}-\mathrm{TiB}_{2}$ ceramic composite [J]. Mat Sci Eng A, 2010, 527(27-28): 7215-7219.

[16] YAMADA S, HIRAO K, YAMAUCHI Y, KANZAKI S. High strength $\mathrm{B}_{4} \mathrm{C}-\mathrm{TiB}_{2}$ composites fabricated by reaction hot-pressing $[\mathrm{J}]$. J Eur Ceram Soc, 2003, 23: 1123-1130.

[17] LEVIN L, FRAGE N, DARIEL M P. The effect of Ti and $\mathrm{TiO}_{2}$ additions on the pressureless sintering of $\mathrm{B}_{4} \mathrm{C}[\mathrm{J}]$. Metall Mater Trans A, 1999, 30: 3201-3210.

\title{
$\mathrm{TiB}_{2}$ 含量对原位反应合成 $\mathrm{TiB}_{2} / \mathrm{B}_{4} \mathrm{C}$ 复合材料的 组织结构和力学性能的影响
}

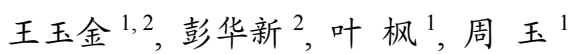

1. 哈尔滨工业大学 材料科学与工程学院, 特种陶瓷研究所, 哈尔滨 150001 ;

2. 布里斯托大学 工学院 航空系, 先进复合材料创新与科学中心, 布里斯托 BS8 1TR, 英国

\begin{abstract}
摘 要: 以 $\mathrm{B}_{4} \mathrm{C}, \mathrm{TiO}_{2}$ 和石墨粉为原料, 采用原位反应热压烧结工艺 $\left(2050{ }^{\circ} \mathrm{C}, 35 \mathrm{MPa}, 1 \mathrm{~h}\right.$ )制备了致密的 $\mathrm{TiB}_{2}$ 含量为 $10 \% \sim 40 \%$ (体积分数)的 $\mathrm{TiB}_{2} / \mathrm{B}_{4} \mathrm{C}$ 复合材料, 并对复合材料的组织结构和力学性能进行了研究。扫描电子 显微镜和透射电子显微镜分析结果表明: 在 $\mathrm{B}_{4} \mathrm{C}$ 晶内及晶界处均匀分布着纳米或亚微米级的 $\mathrm{TiB}_{2}$ 颗粒, 随着 $\mathrm{TiB}_{2}$ 含量的增加, 弹性模量和断裂㓞性明显增大, 而弹性模量和抗弯强度却随之减小。 $40 \%$ (体积分数) $\mathrm{TiB}_{2} / \mathrm{B}_{4} \mathrm{C}$ 复合 材料具有高的断裂韧性, 高达 $8.2 \mathrm{MPa} \cdot \mathrm{m}^{1 / 2}$, 主要增韧机制由微裂纹增韧和裂纹偏转增韧。
\end{abstract}

关键词: $\mathrm{TiB}_{2} / \mathrm{B}_{4} \mathrm{C}$ 复合材料; 原位反应; 增韧机理 